\title{
The sublethal effects of (2,4-Dichlorophenoxy) acetic acid (2,4-D) on narrow-clawed crayfish (Astacus leptodactylus Eschscholtz, 1823)
}

\author{
A. Çağlan Karasu Benli ${ }^{1}$, Duygu Şahin ${ }^{2}$, Mahmut Selvi $^{3}$, Rabia Sarıkaya ${ }^{4}$, Burcu Koçak Memmi ${ }^{5}$, \\ and Aylin Sepici Dinçel ${ }^{2}$
}

Department of Environmental Sciences, Institute of Natural And Applied Sciencel, Faculty of Medicine, Department of Medical Biochemistry ${ }^{2}$, Department of Science Education, Teknikokullar ${ }^{3}$, Department of Primary School Education ${ }^{4}$, Gazi University, Insecticide Test Laboratory, Hacettepe University, Beytepe ${ }^{5}$, Ankara, Turkey

[Received in March 2016; CrossChecked in March 2016; Accepted in November 2016]

\begin{abstract}
2,4-D is a widely used phenoxy herbicide, potentially toxic to humans and biota. The objective of the present study was to reveal short term sublethal effects of 2,4-D on narrow-clawed freshwater crayfish (Astacus leptodactylus Eschscholtz, 1823), based on histology, total haemocyte counts, selected haemolymph parameters, and oxidative stress parameters. In the laboratory conditions crayfish specimens were exposed to $9 \mathrm{mg} \mathrm{L}^{-1}$ of 2,4-D for one week. Experiments were conducted under semi-static conditions in $20 \mathrm{~L}$-capacity aquaria where 10 freshwater crayfish were stocked per aquarium. Exposure (experimental) and control groups were used and the experiments were repeated two times. No mortality and behavioural changes were recorded during the experiments. Total haemocyte counts decreased significantly, while haemolymph glucose levels increased $(P<0.05)$, when compared to the control group. Haemolymph levels of calcium, chloride, sodium, potassium, magnesium, total protein, and lactate did not change. Exposure resulted with increased levels of malondialdehyde (MDA) only in hepatopancreas. However, results of gill FOX assay showed a significant decrease in oxidative stress parameters $(P<0.05)$. MDA levels of gill and abdominal muscle tissues and FOX levels of hepatopancreas and abdominal muscle tissues did not change when compared to the control group. Significant histopathological alterations were observed both in hepatopancreas (multifocal deformations in tubule lumen) and gill tissue (melanisation of gill lamella). Exposure of crayfish even to a sublethal concentration of 2,4-D alters histopathology and lipid peroxidation due to stress. Biomarkers studied here seem to be useful for the assessment of adverse/toxic effects of pesticides on non-target, indicator aquatic organisms.
\end{abstract}

KEY WORDS: haemolymph; herbicide; histology; oxidative stress; toxicity

The first successful selective herbicide, 2,4-dichlorophenoxy acetic acid (2,4-D), was developed in 1946. It belongs to the phenoxy herbicide family and is still one of the systemic herbicides widely used to control many types of broadleaf weeds (1). It is used to control aquatic vegetation, in pasture and rangeland applications, in cultivated agriculture, forest management, home, and garden. It acts by sustaining high levels of the plant hormone auxin, which results in overstimulation of plant growth and death. In addition to this, it causes changes in the animal nervous system based on receptor interaction/interference of acetylcholine. Furthermore, it inhibits the acetyl cholinesterase $(\mathrm{AChE})$ activity and increases the level of serotonin.

Available data on 2,4-D toxicity on aquatic organisms mostly rely on the reports of its acute toxic effects observed in different fish species. Oruc and Uner (4) studied the

Correspondence to: A. Çağlan Karasu Benli, Department of Environmental Sciences, Institute of Natural and Applied Sciences, Gazi University, Teknikokullar, Ankara, Turkey, E-mail: benli@gazi.edu.tr combined effects of azinphosmethyl and 2,4-D on Oreochromis niloticus to clarify the mode of its action on the cellular defence system. Farah et al. (5) studied stress behaviour and acute $96 \mathrm{~h}$ toxicity of three freshwater fish (Heteropneustes fossilis, Clarias batrachus, Channa punctatus) and estimated $\mathrm{LC}_{50}$ values as $81 \mathrm{~m} \mathrm{~L}^{-1}$, $122 \mathrm{mg} \mathrm{L}^{-1}$, and $107 \mathrm{mg} \mathrm{L}^{-1}$. They also calculated $48 \mathrm{~h} \mathrm{LC}_{50}$ in mosquito larvae (Culex pipiens fatigans) as $302 \mathrm{mg} \mathrm{L}^{-1}$. Sarikaya and Yilmaz (6) established $96 \mathrm{~h} \mathrm{LC}_{50}$ of 2,4-D on adult common carp as $63.24 \mathrm{mg} \mathrm{L}^{-1}$. In their study, Sarikaya and Selvi (7) calculated the $48 \mathrm{~h} \mathrm{LC}_{50}$ values for Nile tilapia (O. niloticus L.) larvae and adults as $28.23 \mathrm{mg} \mathrm{L}^{-1}$ and $86.90 \mathrm{mg} \mathrm{L}^{-1}$, respectively.

Potential genotoxic effects of 2,4-D have been reported for the freshwater fish Channa punctatus using the micronucleus test (8); for catfish (Clarias batrachus) by studying micronuclei and erythrocyte alterations (9), and DNA degradation and apoptotic effects (10).

Detrimental effects of 2,4-D on the AChE activity were reported by Fonseca et al. (11), who studied $96 \mathrm{~h}$ effects of 1 and $10 \mathrm{mg} \mathrm{L}^{-1}$ 2,4-D on Leporinus obtusidens. The AChE 
activity of muscle tissue was reduced at both concentrations, as was the case at a concentration of $10 \mathrm{mg} \mathrm{L}^{-1}$ for brain tissue. Liver lactate and protein were significantly reduced after exposure to this herbicide. Plasma protein increased at both exposure concentrations. Catteneo et al. (12) reported an increased $\mathrm{AChE}$ activity in the brain and a decreased activity in muscle tissues after $600 \mathrm{mg} \mathrm{L}^{-1}$ to $700 \mathrm{mg} \mathrm{L}^{-1}$ 2,4-D exposure for $96 \mathrm{~h}$. In the same study, plasma glucose levels increased and vacuolation of hepatocytes and changes in its arrangement cords were observed in animals exposed to $700 \mathrm{mg} \mathrm{L}^{-1}$ of 2,4-D.

Although the effects of 2,4-D were extensively studied in fish, very limited studies have been carried out in invertebrates. In a previous study, Benli et al. (2) estimated the $96 \mathrm{~h} \mathrm{LC}_{50}$ for freshwater crayfish to be $32.6 \mathrm{mg} \mathrm{L}^{-1}$. In addition, 2,4-D exposure has been linked with gonadal tumours in shellfish $(1,13-16)$. Limited information about the effects of this widely used herbicide 2,4-D on the aquatic invertebrate histology and biochemical biomarkers are available in the open literature.

The objective of the present study was to reveal shortterm sublethal effects of 2,4-D on narrow-clawed freshwater crayfish (Astacus leptodactylus Eschscholtz, 1823), based on histology, total haemocyte counts, and measuring the levels of selected haemolymph parameters, as well as to evaluate the changes in basic oxidative stress parameters.

\section{MATERIALS AND METHODS}

\section{Test organism}

The narrow-clawed freshwater crayfish (Astacus leptodactylus Eschscholtz, 1823) was chosen as a representative of freshwater crustaceans, naturally distributed in water bodies around Eurasia (17-19). Crayfish specimens $(\mathrm{N}=60)$ were obtained from a local breeder during the inter-moult stage. Their average weight was $25.36 \pm 3.27 \mathrm{~g}$ and the length was $9.62 \pm 0.43 \mathrm{~cm}$. Crayfish were placed randomly in control and experiment groups, each containing 30 individuals.

\section{Acclimatisation period}

Crayfish were allowed to acclimatise under laboratory conditions for two weeks. During this period, they were fed ad libitum daily with raw fish. The tanks were cleaned by siphoning twice and were aerated constantly. Water temperature was adjusted by thermostatic heaters to $20^{\circ} \mathrm{C}$. All experiments were performed according to the rules of "Guide for the Care and Use of Laboratory Animals" published by the US National Institutes of Health (20).

\section{Test chemical}

2,4-dichlorophenoxy acetic acid (CAS Number: 94-757) was used in the experiments. It was obtained from the
Insecticide Test Laboratory, Hacettepe University, Ankara Turkey. The pesticide was stored at $+4^{\circ} \mathrm{C}$ before use.

\section{Experimental design}

After the two-week acclimatisation period, crayfish were transferred to test tanks, i.e. 25 L-capacity aquaria which contained $20 \mathrm{~L}$ of dechlorinated tap water. The composition of water was: dissolved oxygen $6.60 \pm 0.10 \mathrm{mg} \mathrm{L}^{-1} ; \mathrm{pH}=6.70 \pm 0.03$; conductivity $0.205 \pm 0.01 \mathrm{mS} \mathrm{cm}{ }^{-1}$; total hardness $70 \mathrm{mg} \mathrm{L}^{-1} \mathrm{CaCO}_{3}$; calcium hardness $54 \mathrm{mg} \mathrm{L}^{-1} \mathrm{CaCO}_{3}$. Water temperature was adjusted by thermostatic heaters to $20{ }^{\circ} \mathrm{C}$. During the experiments (except dosing) aquaria were constantly aerated.

\section{Test concentration and exposure}

The test concentration of $9 \mathrm{mg} \mathrm{L}^{-1} 2,4-\mathrm{D}$ was selected as the $25 \%$ of the $96 \mathrm{~h} \mathrm{LC}_{50}$ value $\left(32.6 \mathrm{mg} \mathrm{L}^{-1}\right)$, previously established for freshwater crayfish in a static bioassay test system (2). Under semi-static conditions, ten freshwater crayfish were stocked in each aquarium as a control and an exposure group. Exposure lasted for one week.

\section{Haemolymph analysis}

Following the exposure to $2,4-\mathrm{D}$, the haemolymph samples were taken from experimental animals. They were collected under ice anaesthesia on the basis of the second walking leg using a $2.5 \mathrm{~mL}$ disposable syringe. Briefly, first $0.9 \mathrm{~mL}$ of $4 \%$ heparin was drawn into the syringe. Then $0.1 \mathrm{~mL}$ haemolymph was sampled from freshwater crayfish. Samples were used for determining the total haemocyte counts (THCs) and for haemolymph biochemical analyses. Total haemocyte counts were performed by modifications of the methods of Miller and Stanley (21), Evans (22), and Ward et al. (23). After haemolymph samples were centrifuged at $2500 \mathrm{~g}, 10 \mathrm{~min}$ at $4{ }^{\circ} \mathrm{C}$, biochemical analyses were done by standard analytical techniques. Haemolymph $\mathrm{Na}^{+}, \mathrm{K}^{+}$, and $\mathrm{Cl}^{-}$levels were measured by ISE module of an auto analyser that employed crown ether membrane electrodes for sodium and potassium and a molecularoriented PVC membrane for chloride, which was specific for each ion of interest in the sample (24). Glucose concentrations were analysed by the hexokinase method which is an enzymatic UV test (25). Total protein, calcium, magnesium, and lactic acid were determined using a Beckman CX 7 autoanalyser (Beckman Coulter Inc., Diamond Diagnostics, USA)

\section{Tissue analysis}

After haemolymph sampling, crayfish were sacrificed immediately on ice anaesthesia for histological examination and tissue samples were collected for further analyses of oxidative stress parameters. All tissues were dissected and half of each gill, muscle, and hepatopancreas tissues were 
stored for oxidative stress analysis at $-80{ }^{\circ} \mathrm{C}$. The rest of the tissues (the other half of the hepatopancreas, muscle, gill with antennal gland, gonads digestive tract, and heart) were directly fixed in Davidson's fixative (26).

\section{Histological examination}

After $24 \mathrm{~h}$ fixation in Davidson's fixative, tissues were transferred to $70 \%$ ethyl alcohol. Routine histological tissue processing procedures were carried out as follows: dehydrated in alcohol series, cleared in xylene, embedded in paraffin. The paraffin blocks were sectioned with ThermoShandon 325 Finesse Rotary Microtome (Thermo Fisher Scientific, UK) and stained with hematoxylin and eosin (H\&E). Slides were examined under a light microscope (Carl Zeiss, Germany), coupled with a camera.

\section{Tissue MDA and ferrous oxidation assays}

MDA levels in gills, muscles, and hepatopancreas were determined by the thiobarbituric acid (TBARS) assay (27) Differences in two absorbance measurements from the butanol phase were used as MDA values (nmol per $100 \mathrm{mg}$ of tissue). Additionally, the ferrous oxidation (FOX) assay, which is based on the oxidation of ferrous ions $\left(\mathrm{Fe}^{2+}\right)$ to ferric ions $\left(\mathrm{Fe}^{3+}\right)$ by hydrogen peroxide under acidic conditions was performed for the quantitative determination of low-level lipid hydroperoxides. Results for the FOX assay are given as HP (hydrogen peroxide) equivalents and calculated as nmol g-1 of wet tissue according to HermesLima et al. (28).

\section{Statistical analyses}

The results are the means \pm SD with two replicates. Analysis of data concerning the differences between groups was made using a non-parametric Mann Whitney-U Test. The critical significance level for the statistical tests performed was set at 0.05 .

\section{RESULTS AND DISCUSSION}

\section{Haemolymph analyses}

Following one week exposure to $9 \mathrm{mg} \mathrm{L}^{-1}$ of 2,4-D, the values of total haemocyte counts (THCs) in A. leptodactylus decreased by $25 \%$ as compared to the control group $(P<0.05)$. The results are shown in Figure 1a. Although Le Moullac and Haffner (29) suggested the differences in haemocyte counts as non-specific, depending on the natural rhythms of the environment, and chemical and physicochemical stress, they are generally accepted as reliable/good indicators of stress in crustaceans (29). In their previous studies, Le Moullac and Haffner (29), Smith and Johnston (30), Jussila et al. (31), Jussila et al. (32), and Smith and Johnston (30), reported similar findings for haemocyte counts in other crustaceans exposed to different toxicant and stress factors. For instance, Smith and Johnston (30) observed a significant decrease in THCs and phenoloxidase activity in common shrimp Crangon crangon following exposure to PCB 15 (polychlorinated biphenyl 15). Mello et al. (33) determined a decrease in THCs after exposure to 250 SC Sirus herbicide of pyrazosulfuron-ethyl $0.1 \mu \mathrm{g} \mathrm{L}^{-1}$

(a)

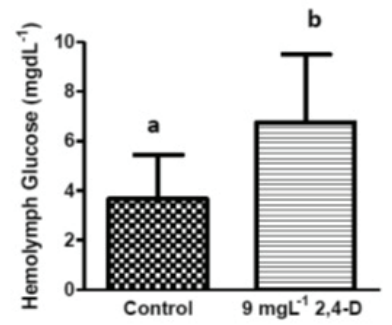

(c)

(b)

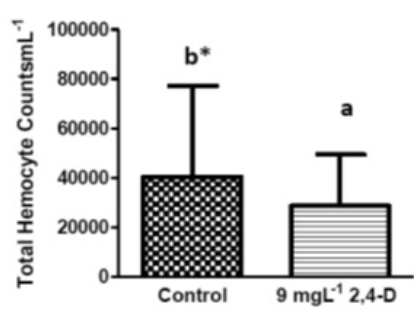

(d)
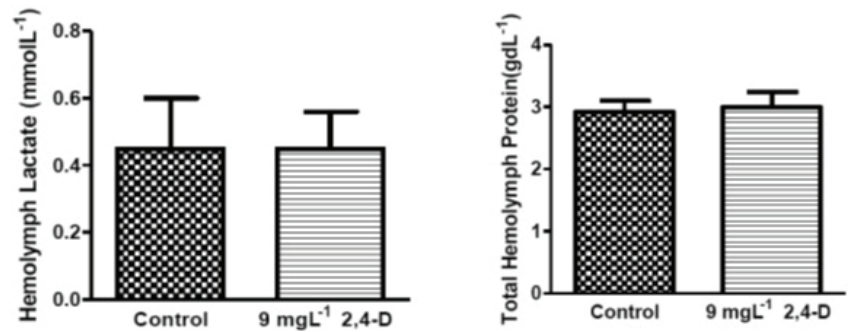

Figure 1 a) Total haemocyte counts , b) haemolymph glucose, c) lactate, and d) total protein levels of freshwater crayfish after oneweek exposure to 2,4-D. *Different small letters indicate significant difference between means $(P<0.05), \quad N=30$ samples/group 
to $1000 \mu \mathrm{g} \mathrm{L}^{-1}$ for $96 \mathrm{~h}$ in Litopenaus vannamei. Qin et al. (34) also observed decreased THCs in freshwater crab Sinopotamon henanense after exposure to $58 \mathrm{mg} \mathrm{L}^{-1}$ and $116 \mathrm{mg} \mathrm{L}^{-1} \mathrm{Cd}$ for $96 \mathrm{~h}$.

In the present study, haemolymph glucose levels increased significantly after exposure to sublethal 2,4-D concentrations. The results are shown in Figure $1 \mathrm{~b}$. Toxicants and other environmental stressors can cause rapid hyperglycaemia in crustaceans just like in vertebrates. Crustaceans require a constant glucose supply for all organs and tissues (ex. muscle and brain). Glucose haemostasis is controlled by the hyperglycaemic hormone $(\mathrm{CHH})$ produced by the X-organ-sinus-gland complex. Chang et al. (35) also found increased haemolymph glucose levels after $24 \mathrm{~h}$ exposure to $0.4 \mathrm{mg} \mathrm{L}^{-1}$ trichlorfon, an organophosphorus insecticide, in $M$. rosenbergii. High haemolymph glucose levels were also found after exposure to various pollutants such as cadmium, organic pollutants, naphthalene, and nitrite in red swamp crayfish, Procambarus clarkii (36), fiddler crab, Uca pugilator (37), U. pugilator (36), and narrow-clawed crayfish (A. leptodactylus) (38).

As seen in Figures 1c and 1d, haemolymph lactate and total protein levels were not altered significantly when compared to the control group. In decapods, lactate is the main product of anaerobic glycolysis; it usually increases in parallel with glucose level increase but slower. Contrary to our results, Bhavan and Geraldine (39) found increased haemolymph lactate levels in Macrobrachium malcolmsonii following exposure to endosulfan (10.6 ng L-1 $16.0 \mathrm{ng} \mathrm{L}^{-1}$, and $32.0 \mathrm{ng} \mathrm{L}^{-1}$ ) for 21 days. Chang et al. (35) observed an increase after $24 \mathrm{~h}$ exposure to $0.4 \mathrm{mg} \mathrm{L}^{-1}$ organophosphorus insecticide trichlorfon in $M$. rosenbergii. Saladkova and Kholodkevich (40) reported protein level in crayfish haemolymph to be a reliable parameter for the physiological state. However, in our study no significant differences were found between the control and exposed groups. Haemocyanin is the predominant protein $(80 \%$ to $95 \%$ of the total protein in the haemolymph) of decapod crustaceans (41) and known to be a biomarker of osmotic stress. Frontera et al. (42) reported unchanged total haemolymph protein values after exposure to $11.25 \mathrm{mg} \mathrm{L}^{-1}$ and $22.5 \mathrm{mg} \mathrm{L}^{-1}$ glyphosate for 50 days.
Our results on the elected haemolymph electrolytes in crayfish exposed to $9 \mathrm{mg} \mathrm{L}^{-1}$ 2,4-D were not significantly different when compared to the control group. Control levels measured for electrolytes were: calcium $\left(36.36 \pm 1.29 \mathrm{mg} \mathrm{dL}^{-1}\right)$, chloride $\left(129.26 \pm 3.00 \mathrm{mEqL}^{-1}\right)$, sodium $\left(193.20 \pm 3.59 \mathrm{mEqL}^{-1}\right)$, potassium $\left(4.56 \pm 0.16 \mathrm{mEq} \mathrm{L^{-1 }}\right)$, and magnesium $\left(4.83 \pm 0.25 \mathrm{mg} \mathrm{dL}^{-1}\right)$. Magnesium and calcium can be suggested as environmental monitoring biomarkers and indicators of crustacean health (43). In another study (35), haemolymph calcium, magnesium, and potassium concentrations were not significantly different among the prawns exposed to 0.1$0.3 \mathrm{mg} \mathrm{L}^{-1}$ trichlorfon (44); while potassium levels also showed no statistically significant differences in the prawns exposed to $0.4 \mathrm{mg} \mathrm{L}^{-1}$ of trichlorfon (35).

\section{Histological analyses}

Seven-day exposure to 2,4-D resulted with histological alterations in gill and hepatopancreas tissues of treated crayfish. However, there were no histological alterations observed in the control groups nor were there changes in other tissues of exposed crayfish, such as the tissues of antennal gland, gonads, muscle, heart, and digestive tract.

In gill tissues, melanisation (Figure 2) and hyperaemia were observed. In the hepatopancreas, multifocal deformation in tubule lumen was seen (Figure 3). Gills are a vital organ for aquatic organisms, which can play important roles in transporting respiratory gases, arranging osmoregulation and ion exchange, and can act as the first barrier for waterborne pollutants. Similar to our results, Bahavan and Geraldine (45) suggested abnormal gill tips in the prawn Macrobrachium rosenbergii exposed to $32 \mathrm{ng} \mathrm{L}^{-1}$ endosulfan. Chang et al. (35) observed structural alterations such as necrotic, hyperplasic, and clavateglobate lamellae with swelling, fusion, and increased mucus secretion in prawns after exposure to $0.4 \mathrm{mg} \mathrm{L}^{-1}$ trichlorfon for $24 \mathrm{~h}$. The tubular structured organ, hepatopancreas of crustaceans is known to be analogous to the mammalian liver, which is also susceptible to xenobiotics such as pesticides. Bahavan and Geraldine (45) reported haemocyte accumulation in the haemocoel space, necrosis in tubules in the prawn Macrobrachium rosenbergii exposed to

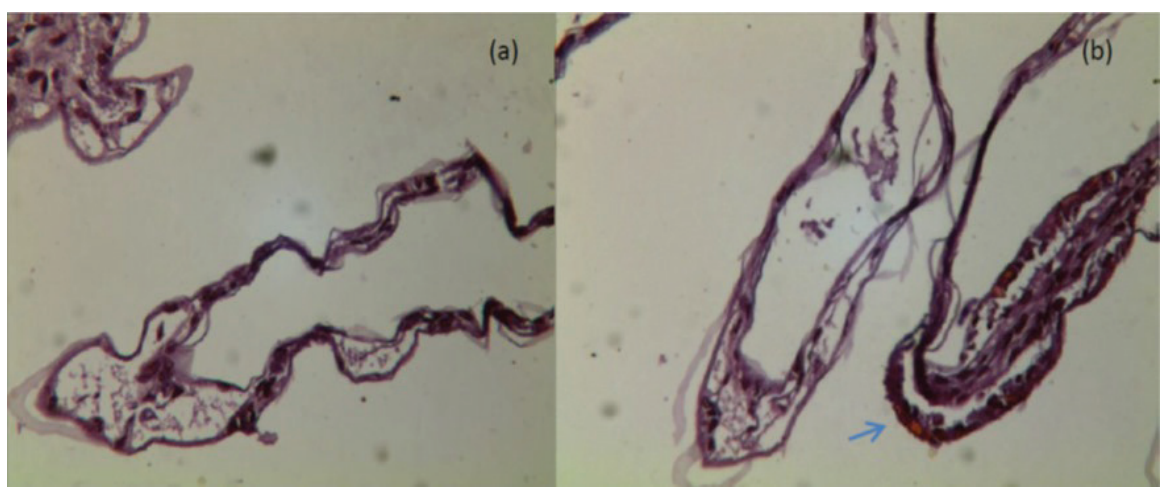

Figure 2 Histological appearance of crayfish (Astacus leptodactylus Eschscholtz, 1823) gill lamella: (a) control (X100, H\&E), (b) Melanisation in gill lamella of crayfish (arrow) (X100, H\&E) 


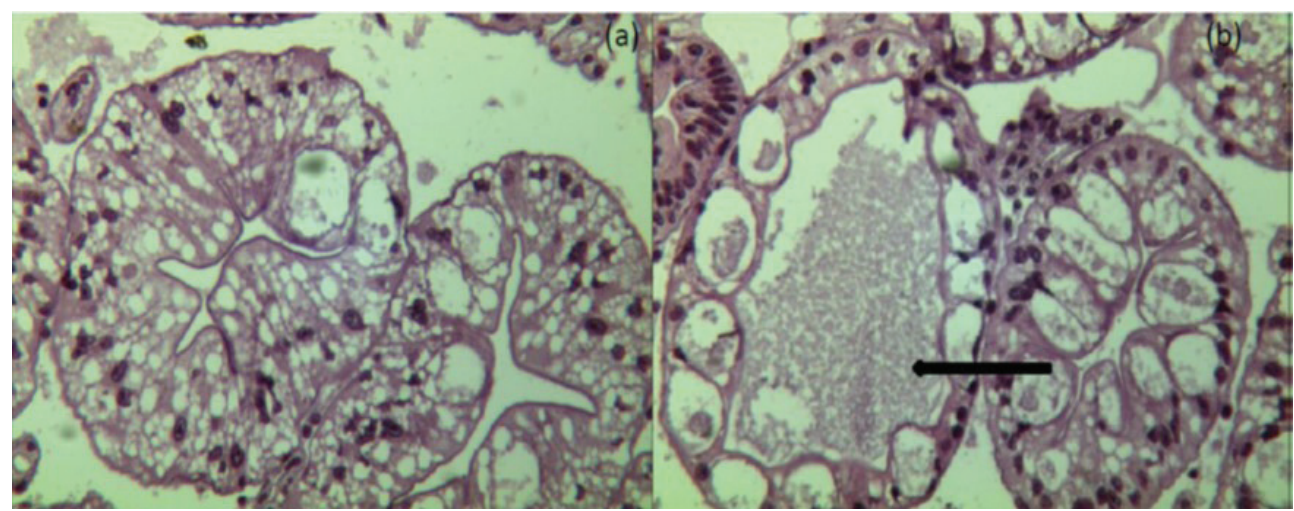

Figure 3 Histology appearance of crayfish (Astacus leptodactylus Eschscholtz, 1823) hepatopancreas (a) control (X100, H\&E) (b) multifocal hepatopancreas deformation in tubule lumen (arrow) (X100, $H \& E)$

$32 \mathrm{ng} \mathrm{L} \mathrm{L}^{-1}$ endosulfan. Chaufan et al. (46) found epithelial disorganisation in hepatopancreas tubules. In addition, diameters and numbers of $\mathrm{B}$ cells increased after being fed with hexachlorobenzen-contaminated Chlorella for three days. As known (47), exposure of crustaceans to pesticides can also lead to histopathological changes such as the interstitial sinus haemocytic infiltration, thickened and/or separated necrotic cells from the basal laminae, melanisation and coagulation in the thickened basal laminae, abnormal lumen of the tubules, necrotic tubules containing tissue debris, and haemocytes can constitute a wall around the thickened basal laminae of the tubules. Such severe histopathological changes were not observed in study.

\section{Biochemical analyses}

The results of radical formation and their pertinent significance to crayfish health after one-week exposure to $9 \mathrm{mg} \mathrm{L}^{-1}$ 2,4-D were shown by MDA and FOX assays in hepatopancreas, abdomen muscle, and gill tissues of narrow-clawed crayfish, and are given in Figure 4. MDA (the end product of lipid peroxidation) levels in hepatopancreas tissues increased after exposure to $9 \mathrm{mg} \mathrm{L}^{-1}$
2,4-D when compared to the control group $(P<0.05)$. Similarly, Hua et al. (48) determined high MDA concentrations in the hepatopancreas of Procambarus clarkii after exposure to $0.01 \mu \mathrm{g} \mathrm{L} \mathrm{L}^{-1}$ deltamethrin for $6 \mathrm{~h}$, a synthetic pyrethroid. Sarikaya et al. (49) reported decreased MDA levels in hepatopancreas after exposure to $5 \mu \mathrm{g} \mathrm{L}^{-1}$, $10 \mu \mathrm{g} \mathrm{L}^{-1}$, and $20 \mu \mathrm{g} \mathrm{L}^{-1}$ of fenitrothion for $24 \mathrm{~h}$. Variation among the studies might be due to different mechanisms of toxic action of the three different pesticide groups. As depicted in Figure 5, the ferrous oxidation assay [FOXHP (hydrogen peroxide) equivalents] results for hepatopancreas and abdomen muscle did not change after exposure to sublethal 2,4-D. However, gill FOX assay results were significantly decreased after exposure to $2,4-\mathrm{D}$. The unchanged FOX assay results in hepatopancreas and abdomen muscle in the present study are in agreement with the results of Sarikaya et al. (47). Peroxidative effects observed in sublethal 2,4-D toxicity may cause damage in gills as an early response of cell/tissue damage seen in parallel with histology results.

In conclusion, the overall results of the present study showed that 2,4-D exposure at its sublethal concentration

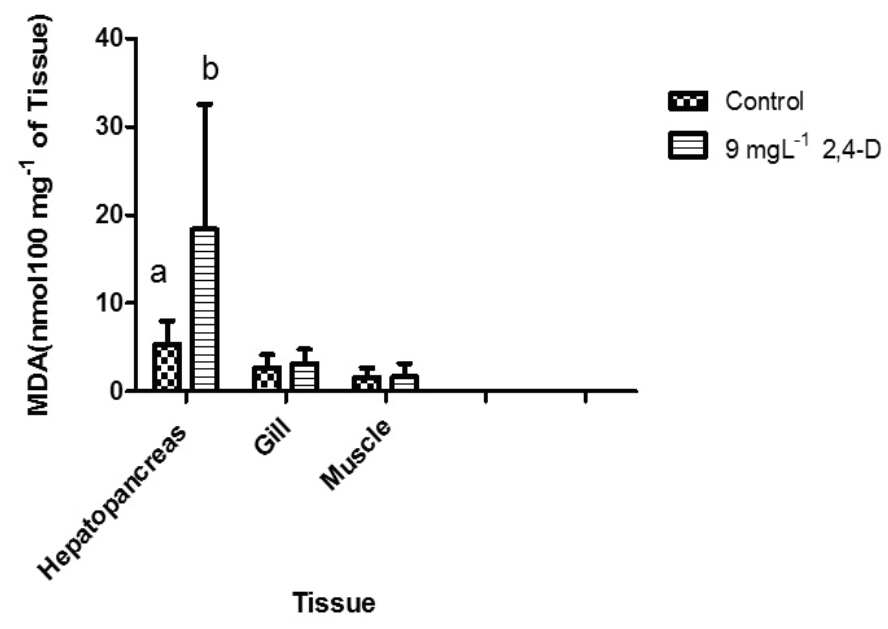

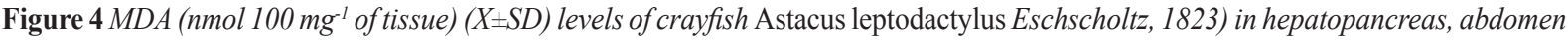
muscle, and gill tissues after one-week exposure to 2,4-D. *Different small letters indicate significant difference between the means $(\mathrm{P}<0.05), \quad N=30$ samples/group 


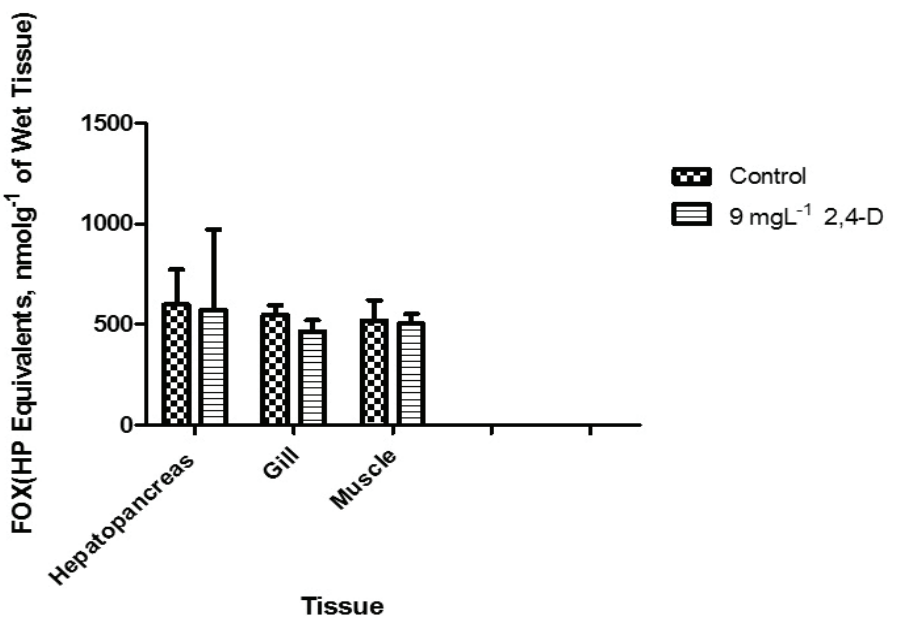

Figure 5 The FOX (HP Equivalents, nmol g-1 of wet tissue) levels of crayfish Astacus leptodactylus Eschscholtz, 1823) in hepatopancreas, abdomen muscle, and gill tissues after one-week exposure to 2,4-D. *Different small letters indicate significant difference between the means $(P<0.05), N=30$ samples/group

did not affect haemolymph electrolytes. However, haemolymph glucose (which is a well-established stress parameter) and total number of haemocytes (which points to an immune reaction) were altered after 2,4-D exposure. Histopathological alterations and oxidative stress were found in hepatopancreas and gill tissues. The obtained results indicate a strong response to tissue damage following treatment, manifested by histological findings, and increased levels of lipid peroxidation markers in crayfish. Such findings suggest that both histological methods and lipid peroxidation markers can be used as reliable ecotoxicological biomarkers: an "early warning system" for the survival of a species, as well as for environmental quality monitoring/protection. Future studies with different model or indicator aquatic species should focus on lipid peroxidation but also elaborate other suitable potential markers useful both in field biomonitoring and under controlled experimental conditions.

\section{Acknowledgements}

The authors would like to thank Dr. Oner Kocak, of the Insecticide Test Laboratory, Hacettepe University, for a generous gift of 2,4-D; The study was partially supported by TUBİTAK (Contract/project no: 109T572).

\section{REFERENCES}

1. Mičić M, Bihari N, Mlinarič-Raščan I. Influence of herbicide, 2,4-dichlorophenoxy acetic acid, on haemocyte DNA of in vivo treated mussel. J Exp Mar Biol Ecol 2004;311:157-69. doi: 10.1016/j.jembe.2004.05.007

2. Benli ACK, Sarıkaya R, Sepici-Dincel A, Selvi M, Şahin D, Erkoc F. Investigation of acute toxicity of (2,4-dichlorophenoxy) acetic acid (2,4-D) herbicide on crayfish (Astacus leptodactylus Esch. 1823). Pest Biochem Physiol 2007;88:296-9. doi: 10.1016/j.pestbp.2007.01.004
3. Bukowska B, Katarzyna Hutnik K. 2,4-D and MCPA and their derivatives: Effect on the activity of membrane erythrocytes acetylcholinesterase (in vitro). Pest Biochem Physiol 2006;85:174-80. doi: 10.1016/j.pestbp.2005.11.009

4. Oruç EO, Üner N. Combined effects of 2,4-D and azinphosmethylon antioxidant enzymes and lipid peroxidation in liver of Oreochromis niloticus. Comp Biochem Physiol 2000;127:291-6. doi: 10.1016/S0742-8413(00)00159-6

5. Farah MA, Ateeq B, Niamat Ali M, Rubina S, Ahmad W. Studies on lethal concentrations and toxicity stress of some xenobiotics on aquatic organisms. Chemosphere 2004;55:25765. doi: 10.1016/j.chemosphere.2003.10.063

6. Sarikaya R, Yilmaz M. Investigation of acute toxicity and the effect of 2,4-D (2,4-dichlorophenoxyacetic acid) herbicide on the behavior of the common carp (Cyprinus carpio L., 1758; Pisces, Cyprinidae). Chemosphere 2003;52:195-201. doi: 10.1016/S0045-6535(03)00106-1

7. Sarıkaya R, Selvi M. Investigation of acute toxicity of 2,4-D (2,4-dichlorophenoxyacetic acid) herbicide on larvae and adult Nile tilapia (Oreochromis niloticus L.). Environ Toxicol Pharmacol 2005;20:264-8. doi: 10.1016/j.etap.2005.01.006

8. Farah MA, Ateeq B, Niamat Ali M, Waseem Ahmad W. Evaluation of genotoxicity of $\mathrm{PCP}$ and 2,4-D by micronucleus test in freshwater fish Channa punctatus. Ecotoxicol Environ Saf 2003;54:25-9. doi: 10.1016/S0147-6513(02)00037-4

9. Ateeq B, Abul Farah M, Niamat Ali M, Ahmad W. Induction of micronuclei and erythrocyte alterations in the catfish Clarias batrachus by 2,4-dichlorophenoxyacetic acid and butachlor. Mutat Res 2002;518:135-44. doi: 10.1016/S13835718(02)00075-X

10. Ateeq B, Abul Farah M, Ahmad W. Evidence of apoptotic effects of 2,4-D and butachlor on walking catfish, Clarias batrachus, by transmission electron microscopy and DNA degradation studies. Life Sci 2006;78:977-86. do1: 10.1016/j. lfs. 2005.06 .008

11. da Fonseca MB, Glusczak L, Moraes BS, de Menezes CC, Pretto A, Tierno MA, Zanella R, Gonçalves FF, Loro VL. The 2,4-D herbicide effects on acetylcholinesterase activity and metabolic parameters of piava freshwater fish (Leporinus obtusidens). Ecotoxicol Environ Saf 2008;69:416-20. doi: 10.1016/j.ecoenv.2007.08.006 
12. Cattaneo R, Loro VL, Spanevello R, Silveira FA, Luzb L, Miron DS, Fonseca MB, Moraes BS, Clasen B. Metabolic and histological parameters of silver catfish (Rhamdia quelen) exposed to commercial formulation of 2,4-dichlorophenoxiacetic acid (2,4-D) herbicide. Pest Biochem Physiol 2008;92:133-7. doi: 10.1016/j. pestbp.2008.07.004

13. Gardner GR, Yevich PP, Hurst J, Thayler P, Benyi S, Harshbarger JC, Pruell RJ. Germinomas and teratoid siphon anomalies in softshell clams Mya arenaria, environmentally exposed to herbicides. Environ Health Perspect 1991;90:4351. do1: $10.2307 / 3430844$

14. Vanbeneden RJ, Gardner GR, Blake NJ, Blair DG. Implications for the presence of transforminggenes in gonadal tumours in 2 bivalve mollusk species. Cancer Res 1993;53:2976-9.

15. Vanbeneden RJ. Molecular analysis of bivalve tumoursmodels for environmental genetic interactions. Environ Health Perspect 1994;102(Suppl 12):81-3. PMCID: PMC1566730

16. Vanbeneden RJ. Environmental effects and aquatic organisms-investigations of molecular mechanisms of carcinogenesis. Environ Health Perspect 1997;105(Suppl 3):669-74. PMCID: PMC1469911

17. Köksal G. Astacus leptodactylus in Europe. In: Holdich DM, Lowery R, editors. Freshwater crayfish biology, management and exploitation. London: Croom Helm; 1988. p. 365-400.

18. Harlıoğlu MM. The present situation of freshwater crayfish, Astacus leptodactylus (Eschscholtz, 1823) in Turkey. Aquaculture 2004;230:181-7. doi: 10.1016/S00448486(03)00429-0

19. Klobučar GI, Malev O, Šrut M, Štambuk A, Lorenzon S, Cvetković Ž, Ferrero EA, Maguire I. Genotoxicity monitoring of freshwater environments using caged crayfish (Astacus leptodactylus). Chemosphere 2012;87:62-7. doi: 10.1016/j. chemosphere.2011.11.060

20. National Research Council (US) Committee for the Update of the Guide for the Care and Use of Laboratory Animals. Guide for the Care and Use of Laboratory Animals. 8th edition. Washington (DC): National Academies Press (US); 2011. Available from: https://www.ncbi.nlm.nih.gov/books/ NBK54050/ doi: 10.17226/12910.

21. Miller JS, Stanley DW. Investigation an immune response to bacterial infection. In: Karcher SJ, editor. $21^{\text {st }}$ Annual Conference of the Association for Biology Laboratory Education (ABLE) University of Nebraska; 1-5 June 1999; Lincoln, Nebraska. Lincoln: The Association for Biology Laboratory Education; 1999; p. 133-45.

22. Evans L. 1998/304-Pilot Study Of Disease Conditions In All Potential Rock Lobster Aquaculture Species At Different Growth Stages, 2003 [displayed 7 November 2016]. Available at http://espace.library.curtin.edu. $\mathrm{au} / \mathrm{R}$ ?func $=$ dbin-jump-full\&object_id $=19680$

23. Ward RJ, McChrohan $\mathrm{CR}$, White $\mathrm{KN}$, Influence of aqueous aluminium on the immune system of the freshwater crayfish Pacifasticus leniusculus. Aquat Toxicol 2006;77:222-8. doi: 10.1016/j.aquatox.2005.12.006

24. Tietz NW, Prudan EL, Siggaard-Andersen O. Electrolytes. In: Tietz NW, editor. Fundamentals of clinical chemistry. Philadelphia: WB Saunders Co.; 1987. p. 614-24.
25. Bergmeyer HU, Grassl M, Walter HE. in Methods of Enzymatic Analysis (Bergmeyer, H.U. ed) $3^{\text {rd }}$ ed., Volume II, , Verlag Chemie, Deerfield Beach, FL.1983: 222-3.

26. Bell TA, Lightner DV. A Handbook of Normal Penaeid Shrimp Histology, Baton Rouge (LA): The World Aquaculture Society; 1988.

27. Mihara M, Uchiyama M. Determination of malonaldehyde precursor in tissues by thiobarbituric acid test. Anal Biochem 1978;86:271-8. doi: 10.1016/0003-2697(78)90342-1

28. Hermes-Lima M, Willmore GW, Storey BK. Quantification of lipid peroxidation in tissue extracts based on Fe(III)xylenol orange complex formation. Free Radic Biol Med 1995;19:27180. doi: 10.1016/0891-5849(95)00020-X

29. Le Moullac G, Haffner P. Environmental factors affecting immune responses in Crustacea. Aquaculture 2000;191:12131. doi: 10.1016/S0044-8486(00)00422-1

30. Smith VJ, Johnston PA. Differential haemotoxic effect of PCB congeners in the common shrimp, Crangon crangon. Comp Biochem Physiol C 1992;101:641-9. PMID: 1354143

31. Jussila J, Jago J, Tsvetnenko E, Dunstan B, Evans LH. Total and differential hemocyte counts in western rock lobsters (Panulirus cygnus George) under postharvest stress. Mar Freshwater Res 1997;48:863-7. doi: 10.1071/MF97216

32. Jussila J, Paganini M, Mansfield S, Evans LH. On physiological responses, plasma glucose, total hemocyte counts and dehydration of Marron Cherax tenuimanus (Smith) to handling and transportation under simulated conditions. In: Proceedings of the $12^{\text {th }}$ International Symposium on Freshwater Crayfish 12; 3-9 August 1998; Augsburg, Germany. Augsburg: Weltbild Verlag; 1999. p. 54-167.

33. Mello GL, Júnior HA, Garcia S, Vinatea L. Acute toxicity of pyrazosulfuron-ethyl and permethrin to juvenile Litopenaeus vannamei. Biological Sciences. Acta Scientiarum 2011;33:1-6. doi: 10.4025/actascibiolsci.v33i1.6974

34. Qin Q, Qin S, Wang L, Lei W. Immune responses and ultrastructural changes of hemocytes in freshwater crab Sinopotamon henanense exposed to elevated cadmium. Aquat Toxicol 2012;106-107:140-6. doi: 10.1016/j. aquatox.2011.08.013

35. Chang CC, Lee PP, Hsu JP, Yeh SP, Cheng W. Survival and biochemical, physiological, and histopathological responses of the giant freshwater prawn, Macrobrachium rosenbergii, to short-term trichlorfon exposure. Aquaculture 2006;253:65366. doi: 10.1016/j.aquaculture.2005.05.011

36. Reddy PS, Devi M, Sarojini R, Nagabhushanam R, Fingerman M. Cadmium chloride induced hyperglycemia in the red swamp crayfish, Procambarus clarkii: Possible role of crustacean hyperglycemic hormone. Comp Biochem Physiol C 1994;107:57-61. doi: 10.1016/13678280(94)90010-8

37. Reddy PS, Katyayani RV, Fingerman M. Cadmium and naphthalene-induced hyperglycemia in the fiddler crab, $U \mathrm{ca}$ pugilator: Differential modes of action on the neuroendocrine system. Bull Environ Contam Toxicol 1996;56:425-31. doi: 10.1007/s001289900061

38. Yildiz HY, Benli ACK. Nitrite toxicity to crayfish, Astacus leptodactylus, the effects of sublethal nitrite exposure on hemolymph nitrite, total hemocyte counts, and hemolymph glucose. Ecotoxicol Environ Saf 2004;59:370-5. do1: 10.1016/j.ecoenv.2003.07.007 
39. Bhavan PS, Geraldine P. Biochemical stress responses in tissues of the prawn Macrobrachium malcolmsonii on exposure to endosulfan. Pest Biochem Physiol 2001;70:2741. doi: 10.1006/pest.2001.2531

40. Sladkova SV, Kholodkevich SV. Total protein in hemolymph of crawfish Pontastacus leptodactylus as a parameter of the functional state of animals and a biomarker of quality of habitat. J Evol Biochem Physiol 2011;47:160-7. doi: 10.1134/ S0022093011020058

41. Bhavan PS, Geraldine P. Alterations in concentrations of protein, carbohydrate, glycogen, free sugar and lipid in the prawn Macrobrachium malcolmsonii on exposure to sub lethal concentrations of endosulfan. Pest Biochem Physiol 1997;58:89-101. do1: 10.1006/pest.1997.2287

42. Frontera JL, Vatnick I, Chaulet A, Rodriguez EM. Effects of glyphosate and polyoxyethylenamine on growth and renergetic reserves in the freshwater crayfish Cherax quadricarinatus (Decapoda, Parastacidae). Arch Environ Contam Toxicol 2011;61:590-8. doi: 10.1007/s00244-0119661-3

43. Noga EJ. Hemolymph biomarkers of crustacean health. In: Fingerman M. Nagabhushanam R, editors. Recent advances in marine biotechnology, Immunobiology and pathology. Vol. 5. Enfield (NH): Science Publishers Inc.; 2000, p. 12563.

44. Yeh SP, Sung TG, Chang CC, W Cheng, Kuo CM. Effects of an organophosphorus insecticide, trichlorfon, on hematological parameters of the giant freshwater prawn,
Macrobrachium rosenbergii (de Man). Aquaculture 2005;243:383-92. doi: 10.1016/j.aquaculture.2004.10.017

45. Bhavan PS, Geraldine P. Histopathology of the hepatopancreas and gills of the prawn Macrobrachium malcolmsonii exposed to endosulfan. Aquat Toxicol 2000;50:331-9. doi: 10.1016/ S0166-445X(00)00096-5

46. Chaufan G, Juárez AB, Basack S, Iturralde E, Sabatini SE, Genovese G, Onet OML, Kesten E, Ríos de Molina MC. Toxicity of hexachlorobenzene and its transference from microalgae (Chlorella kessleri) to crabs (Chasmagnathus granulatus). Toxicology 2006;227:262-70. doi: 10.1016/j. tox.2006.08.011

47. Negro LE, Montagna M, Collins P. Freshwater decapods and pesticides: an unavoidable relation in the modern world. In: Stoytcheva M, editor. Pesticides in the modern world - risks and benefits. Rijeka: In Tech; 2012. p. 197-225.

48. Wei H, Wu N, Shen H, Cheng Y, Wu T. Oxidative stress of deltamethrin to the liver of crayfish (Procambarus clarkii). J Fish China 2010;34:733-9. doi: 10.3724/ SP.J.1231.2010.06709.

49. Sarikaya R, Sepici-Dinçel A, Cağlan Karasu Benli A, Selvi $\mathrm{M}$, Erkoç F. The acute toxicity of fenitrothion on narrowclawed crayfish (Astacus leptodactylus Eschscholtz, 1823) in association with biomarkers of lipid peroxidation. J Biochem Mol Toxicol 2011;25:169-74. doi: 10.1002/ jbt.20373.

\section{Subletalni učinci 2,4-diklorofenoksi octene kiseline (2,4-D) na slatkovodnog uskoškarog raka (Astacus leptodactylus Eschscholtz, 1823)}

2,4-D je fenoksi herbicid koji se upotrebljava diljem svijeta, a potencijalno je toksičan za ljude i biotu. Cilj ovoga istraživanja bio je ispitati kratkoročne subletalne učinke herbicida 2,4-D na slatkovodnog uskoškarog raka (Astacus leptodactylus Eschscholtz, 1823) proučavanjem histoloških promjena, ukupnog broja hemocita, odabranih hemolitičkih parametara i parametara oksidacijskoga stresa. Jedinke slatkovodnog raka izložene su u laboratorijskim uvjetima koncentraciji od $9 \mathrm{mg} \mathrm{L}^{-1}$ herbicida 2,4-D tijekom sedam dana. Eksperimenti su izvedeni u polustatičkim uvjetima u 20-litarskim akvarijima. U svakom akvariju držano je 10 jedinki rakova, podijeljenih u skupinu koja je bila izložena herbicidu i u kontrolnu skupinu, a eksperiment je ponovljen tri puta. Tijekom eksperimenata nisu zabilježene nikakve promjene u stopi smrtnosti ili u ponašanju životinja. Ukupan se broj hemocita značajno smanjio, a razine glukoze $u$ hemolimfi povećale $(P<0,05)$ u usporedbi s kontrolnom skupinom. Razine kalcija, klorida, kalija, magnezija, ukupnog proteina i laktata $u$ hemolimfi nisu se promijenile. Izlaganje herbicidu povisilo je razine malondialdehida (MDA) $u$ hepatopankreasu. Međutim, rezultati FOX-testa na škrgama pokazali su značajno smanjenje parametara oksidacijskoga stresa $(P<0,05)$, za razliku od razina MDA izmjerenih FOX-testom u škrgama i abdominalnom mišićnom tkivu te $\mathrm{u}$ hepatopankreasu, koje se nisu promijenile. Uočene su značajne histopatološke promjene u tkivu hepatopankreasa (multifokalne deformacije tubularnog lumena) i škrga (melanizacija škržnih listića). Izlaganje rakova subletalnoj koncentraciji herbicida 2,4-D izazvalo je histopatološke promjene te potaknulo lipidnu peroksidaciju zbog stresa. Čini se da su biomarkeri koji su promatrani u ovom ispitivanju korisni za procjenu neželjenih učinaka pesticida na neciljne vodene indikatorske organizme. 